九州大学学術情報リポジトリ

Kyushu University Institutional Repository

\title{
Alkaline Extraction of DNA from Pathogenic Fungi for PCR-RFLP Analysis
}

Matsumoto, Masaru

Laboratory of Plant Pathology, Faculty of Agriculture, Kyushu University

Mishima, Shinobu

Laboratory of Plant Pathology, Faculty of Agriculture, Kyushu University

Matsuyama, Nobuak i

Laboratory of Plant Pathology, Faculty of Agriculture, Kyushu University

https://doi.org/10.5109/24186

出版情報 : 九州大学大学院農学研究院紀要. 42 (1/2)，pp.23-26，1997-12. Kyushu University バージョン：

権利関係 : 


\title{
Alkaline Extraction of DNA from Pathogenic Fungi for PCR-RFLP Analysis
}

\author{
Masaru Matsumoto, Shinobu Mishima and Nobuaki Matsuyama
}

Laboratory of Plant Pathology, Faculty of Agriculture,

Kyushu University, Fukuoka 812-81, Japan

(Received July 22, 1997 and accepted August 25, 1997)

\begin{abstract}
For the preparation of DNA samples from fungal mycelia alkaline extraction method was applied and assessed its usefulness for PCR-RFLP analysis. Using alkaline treatment protocols, 18S ribosomal DNAs (rDNA) derived from fungal genomic DNA of Pyricularia oryzae, $P$. zingiberi, Rhizoctonia solani and R. oryzae were PCR-amplified and digested with Hha I, Msp I and Hae II. RFLP analysis with HhaI showed the divergent polymorphism between genus Pyricularia and Rhizoctonia. The alkaline DNA extraction method saves the time and labor required for DNA sample preparation and seemed to be useful for rapid identification of specific fungal species by PCR-RFLP analysis.
\end{abstract}

\section{INTRODUCTION}

The polymerase chain reaction (PCR) has been used for amplifying specific DNA sequences in isolates of Rhizoctonia species and restriction fragment length polymorphism (RFLP) analysis of these amplified products has revealed the possibility of rapid identification of Rhizoctonia species (Matsumoto et al., 1996a; 1996b). However, DNA sample preparation from fungal mycelia is often time-consuming and several protocols for DNA preparation involve multiple steps. Since PCR requires only a minute quantity of template DNA for successful amplification and a crude DNA preparation is enough for PCR, it might be possible to extract sufficient DNA by a simplified method.

An alkaline DNA extraction method with $\mathrm{NaOH}$ was successfully introduced to prepare DNA samples in many plant species for PCR assaying (Wang et al., 1993). This method allowed sufficient DNA extraction without any inhibition for the amplification. Improvement of a rapid DNA extraction method will lead to the development of ability of PCR-RFLP analysis for large number of isolates. The aim of this study is to assess the value of an alkaline DNA extraction method for rapid detection and identification of specific phytopahogenic fungi by PCR-RFLP analysis.

\section{MATERIALS AND METHODS}

For effective trials, an $18 \mathrm{~S}$ ribosomal RNA (rRNA) gene from Pyricularia oryzae, $P$. zingiberi, Rhizoctonia solani and $R$. oryzae was chosen as the sequence to be amplified. The isolates used in this study were listed in Table 1. All isolates were maintained on a slant culture of potato-dextrose agar (Funakoshi Chem. Co.). Primers NS 1 (5'-GTAGTCATATGCTTGTCTC-3') and NS 2 (5'-GGCTGCTGGCACCAGACTTGC3') amplified partial length of 18S rRNA genes (White et al., 1990). DNA samples for PCR 
Table 1. List of isolates of Pyricularia spp. and Rhizoctonia spp. used.

\begin{tabular}{llll}
\hline Species & Isolates & Origin & Source \\
\hline$P$. oryzae & TH $67-22$ & Rice & AKU \\
& TH $68-86$ & Rice & AKU \\
& KEN 53-33 & Rice & AKU \\
& KEN 60-19 & Rice & AKU \\
\hline$P$. zingiberi & NNZiM 1-1-1 & Mioga & AKU \\
& NNZiM 2-2-1 & Mioga & AKU \\
& FOZiM 1-2-1 & Mioga & AKU \\
& YNZiM 1-1-1 & Mioga & AKU \\
\hline R. oryzae & Ro-0105 & Rice & AKU \\
& M23 & Rice & AKU \\
& C-505 & Rice & AKU \\
& R-1 & Rice & AKU \\
\hline R. solani & Cs-Ka & Rice & ATCC 76121 \\
& C-325 & Rice & IFO 30935 \\
& C-326 & Rice & IFO 30936 \\
& Cs-2 & Rice & AHU \\
\hline
\end{tabular}

a) AKU: Faculty of Agriculture, Kyushu University, Fukuoka, Japan.

b) AMU: Faculty of Agriculture Meijyou University, Nagoya, Japan.

c) ATCC: American Type Culture Collection, USA.

d) IFO: Institute for Fermentation, Osaka, Japan.

e) AHU: Faculty of Agriculture, Hokkaido University, Hokkaido, Japan

were prepared from fungal mycelia according to following protocols. Lyophilized mycelia, which were grown in a liquid nutrient-broth medium at $28^{\circ} \mathrm{C}$ for 7 days, were placed into $1.5 \mathrm{ml}$ of Eppendorf tube, and roughly ground with $10 \mu \mathrm{l}$ of $0.5 \mathrm{~N} \mathrm{NaOH}$ until no large pieces of mycelia are left. Five $\mu \mathrm{l}$ of $\mathrm{NaOH}$ solution were transferred quickly to a new Eppendorf tube containing $495 \mu \mathrm{l}$ of $20 \mathrm{mM}$ Tris- $\mathrm{HCl}(\mathrm{pH} 8.0)$, mixed well and the $5 \mu \mathrm{l}$ of this DNA extract was used for PCR assaying. PCRs were carried out in a $100 \mu \mathrm{l}$ of reaction volume. A $5 \mu \mathrm{l}$ of DNA extract was added to $95 \mu \mathrm{l}$ of reaction mixture as recommended by the manufacturer using Tth DNA polymerase (Toyobo Biochem. Co.). The thermal cycles were conducted 30 times, with parameters of $1 \mathrm{~min}$ at $94^{\circ} \mathrm{C}, 2 \mathrm{~min}$ at $50^{\circ} \mathrm{C}$ and 3 min at $72^{\circ} \mathrm{C}$.

The enzymes, Hha I, Msp I and Hae III, were used for restriction fragment analysis to differentiate Pyricularia species and Rhizoctonia species. Restricted DNA was analyzed by electrophoresis in 3\% agarose gel (Katayama Chem. Co.) in TBE buffer (100 $\mathrm{mM}$ Tris-HCl, $20 \mathrm{mM}$ EDTA, $100 \mathrm{mM}$ boric acid, $\mathrm{pH}$ 8.3). Gels were stained with ethidium bromide (Sigma Chem. Co.) and photographed under UV light (312 nm).

\section{RESULTS AND DISCUSSION}

Using the alkaline DNA extraction protocols, specific PCR-amplified products, a single 

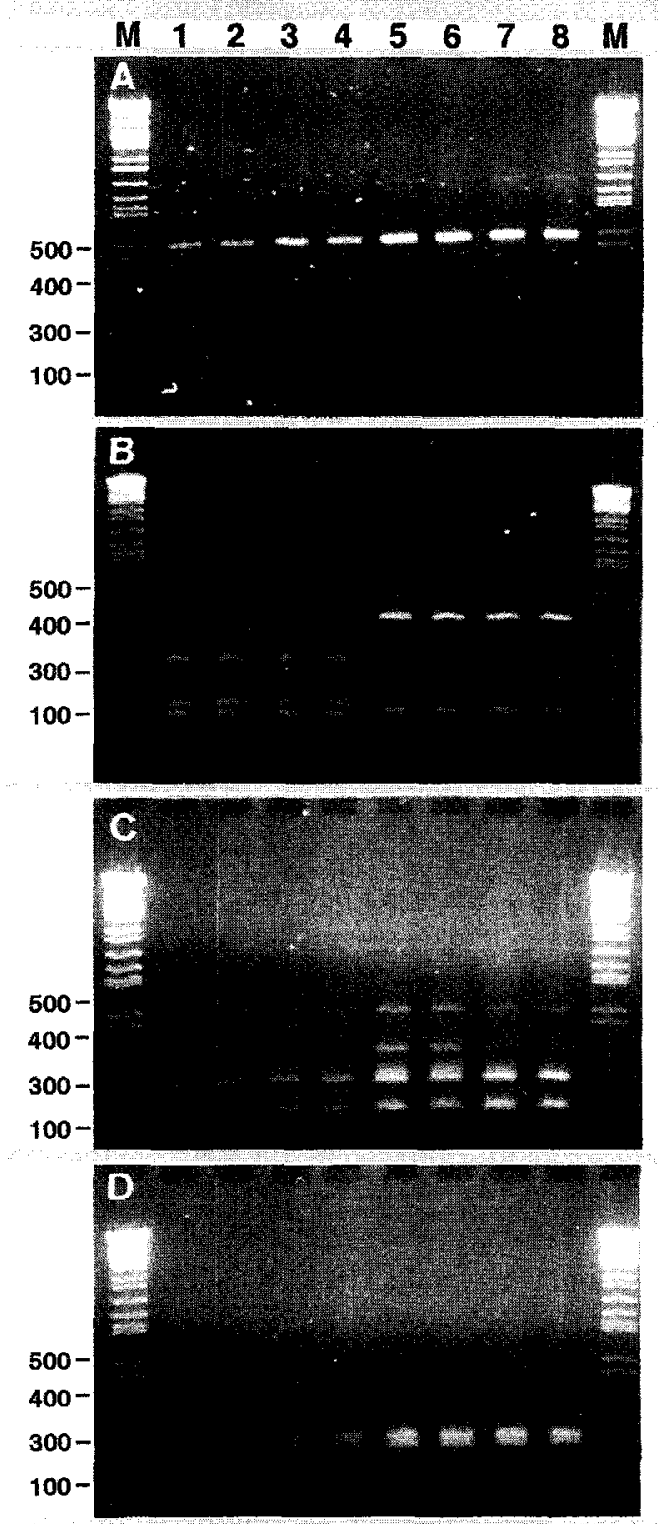

Fig. 1. Electrophoretic patterns of PCR-amplified $18 \mathrm{~S}$ rDNA of Pyricularia spp. and Rhizoctonia spp. (A) and restriction fragments patterns of amplified products after digestion with $H h a I$ (B), Msp I (C) and Hae III (D), P. oryzae, Lane 1 and $2 ; P$. zingiberi, Lane 3 and $4 ; R$. solani, Lane 5 and $6 ; R$. oryzae, Lane 7 and $8 ; \mathrm{M}$; IDNA size marker of $\lambda$-DNA digested with EcoRI and Hind III. 
Table 2. Sizes (bp) of DNA fragment generated after digestion of $18 \mathrm{~S}$ rDNA from Pyricularia spp. and Rhizoctonia spp. with three restriction enzymes.

\begin{tabular}{llll}
\hline & \multicolumn{3}{c}{ Restriction enzymes } \\
\cline { 2 - 4 } Strain & Hha I & Msp I & Hae II \\
\hline P. oryzae & $120,140,340$ & 180,360 & 210,340 \\
P. zingiberi & $120,140,340$ & 180,360 & 210,340 \\
R. oryzae & 110,490 & 180,360 & 210,340 \\
R. solani & 110,490 & 180,360 & 210,340 \\
\hline
\end{tabular}

size of putative 600-bp fragment, were obtained in all isolates of $P$. oryzae, $P$. zingiberi, $R$. solani and $R$. oryzae (Fig. 1A). Specific digestion profiles of PCR-amplified 18S rDNA with Hha I, Msp I and Hae III were presented by electrophoresis (Fig. 1B-1D; Table 2). Weak bands observed in digestion products of $P$. oryzae and $P$. zingiberi could be responsible for the low concentration of DNA sample. Digestion with Msp I and Hae III did not show any polymorphisms (Fig. 1C and 1D). After digestion of PCR-amplified 18S rDNA products with $M s p I$, all tested isolates showed equal sets of 180 - and 360-bp fragments (Fig. 1C; Table 2). In the cases of $R$. solani and $R$. oryzae, bands other than these two bands were also detected (Fig. 1C) and this could be responsible for the high concentration of the sample. Digestion with Hae III presented equal sets of 210- and 340bp fragments for all isolates (Fig. 1D; Table 2). The digestion with Hha I resulted distinct polymorphisms and produced unique sets of 120-, 140- and 340-bp fragments for isolates of Pyricularia spp., and 110- and 490-bp fragments for isolates of Rhizoctonia species, respectively (Fig. 1B; Table 2).

The alkaline DNA extraction method was successfully applied for DNA sample preparation from fungal mycelia at PCR and following RFLP analysis. By alkaline ( $\mathrm{NaOH})$ extraction, multiple steps required previously for DNA sample preparation was avoided. This rapid and easy method will be useful for PCR assaying of large numbers of isolates. Because of its instability of the prepared DNA samples at $-20^{\circ} \mathrm{C}$ as alkaline solution, a series of their experimental operation has to be done quickly and DNA samples should be supplied for PCR right away after the extraction.

\section{REFERENCES}

Matsumoto, M., N. Furuya, Y. Takanami and N. Matsuyama 1996a RFLP analysis of the PCR-amplified $28 \mathrm{~S}$ rIDNA in Rhizoctonia solani. Mycoscience, 37: 351-356

Matsumoto, M., N. Furuya and N. Matsuyama 1996b PCR-RFLP analysis of amplified 28S ribosomal DNA for identification of Rhizoctonia spp., the causal agents of sheath diseases of rice plants. J. Fac. Agr. Kyushu Univ, 41: 39-44

Wang, H., M. Qi and A. J. Cutler 1993 A simple method of preparing plant samples for PCR. Nucleic Acid Research, 21: 4153-4154

White, T. J., T. Bruns, S. Lee and J. Taylor 1990 Amplification and direct sequencing of fungal ribosomal RNA genes for phylogenetics. In "PCR Protocols" by N. Inuis, D. Gefland, J. Sninsky and T. White, Academic Press, New York, pp. 315-322 